\title{
Лабораторні дослідження впливу засобів ураження на броньову перешкоду
}

\section{Laboratory studies of the influence of weapons on an armored obstacle}

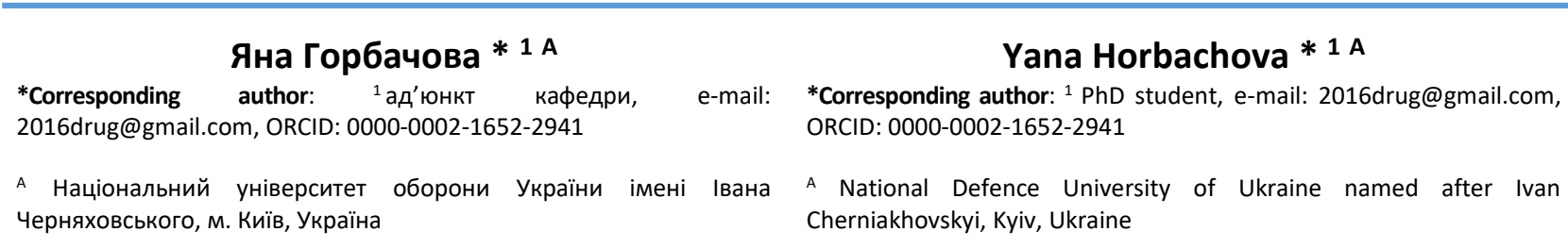

Received: February 2, 2022 | Revised: February 22, 2022 | Accepted: February 28, 2022

DOI: $10.33445 /$ sds.2022.12.1.8

Мета роботи: Провести лабораторні дослідження впливу засобів ураження на додаткову та основну броньову перешкоду та отримати статистичні дані, які дозволять побудувати поліноміальну залежність впливу кінетичної енергії засобу ураження на корпус бойових броньованих машин.

Дизайн/Метод/Підхід дослідження: Для оцінювання стійкості додаткового бронювання обрана методика дослідження параметрів пробою з реєстрацією ударного імпульсу, що дозволяє проводити експрес-оцінку опору матеріалів деформуванню й руйнуванню при наскрізному пробитті. Лабораторне дослідження було проведено за допомогою балістичного маятника, балістичного ствола, вимірювача швидкості та іншого необхідного лабораторного устаткування.

Результати дослідження: За допомогою лабораторного обладнання отримані статистичні дані, які дозволять, в подальшому, побудувати поліноміальну залежність впливу кінетичної енергії засобу ураження на броньову перешкоду та корпус бойової броньованої машини.

Теоретична цінність дослідження: Під час випробувань буде перевірено і підтверджено теоретичні підходи або їх спростовано щодо ефективності використання додаткового захисту, а саме додаткової броньової перешкоди, а побудовані поліноміальні моделі дадуть можливість вибирати оптимальні параметри додаткового бронювання.

Практична цінність дослідження: Результати дослідження можуть бути використані при створенні додаткового захисту бойових броньованих машин від засобів ураження кінетичної дії до 14,5мм.

Оригінальність / Цінність дослідження: Побудована в результаті багатофакторного експерименту закономірність впливу засобів ураження на броньову перешкоду вперше враховує: відстань від броньової перешкоди до броні, кут зустрічі засобу ураження із броньовою перешкодою та товщину додаткової броньової перешкоди.

Майбутні дослідження: дослідження відкриває шляхи для майбутніх досліджень стійкості броньової перешкоди до засобів ураження. Отримані результати можуть бути використані для визначення впливу засобів ураження, а саме кулі 7,62 мм, 12,7 мм, 14,5 мм на додаткову броньову перешкоду, що дасть можливість визначати мінімально-необхідний рівень додаткового бронювання.

Тип статті: практичний

Ключові слова: засоби ураження, броньова перешкода, лабораторне дослідження, балістичний маятник, математична модель.
Purpose: Conduct laboratory studies of the impact of means of destruction on the additional and main armor barrier and obtain statistical data that will build a polynomial dependence of the impact of kinetic energy of the means of destruction on the body of armored combat vehicles.

Design/Method/Approach: To assess the stability of additional booking, the method of studying the parameters of the breakdown with the registration of the shock pulse was chosen, which allows for rapid assessment of the resistance of materials to deformation and destruction during through penetration. The laboratory study was performed using a ballistic pendulum, ballistic barrel, speedometer and other necessary laboratory equipment.

Findings: With the help of laboratory equipment, statistical data were obtained, which will allow, in the future, to build a polynomial dependence of the kinetic energy of the means of destruction on the armor barrier and the body of the armored combat vehicle.

Theoretical implications: During the tests, theoretical approaches will be tested and confirmed or refuted in terms of the effectiveness of additional protection, namely additional armor barrier, and built polynomial models will allow you to choose the optimal parameters of additional booking.

Practical implications (if applicable): The results of the study can be used to create additional protection of armored combat vehicles from means of destruction of kinetic action up to 14.5 $\mathrm{mm}$.

Originality/Value: Constructed as a result of a multifactor experiment the regularity of the impact of the means of destruction on the armor barrier for the first time takes into account: the distance from the armor barrier to armor, the angle of contact of the weapon with the armor barrier and the thickness of the additional armor barrier.

Future research: This study paves the way for future studies of the resistance of the armor barrier to the means of destruction. The obtained results can be used to determine the impact of the means of destruction, namely bullets $7.62 \mathrm{~mm}, 12.7 \mathrm{~mm}$, $14.5 \mathrm{~mm}$ on the additional armor barrier, which will determine the minimum required level of additional armor.

Papertype: practical.

Key words: means of destruction, armor barrier, laboratory research, ballistic pendulum, mathematical model. 


\section{Bcmyn}

На сьогодні на озброєнні Збройних Сил України перебуває велика кількість бойових броньованих машин (ББМ) колишнього Союзу Радянських Соціалістичних Республік. Ця бойова техніка вже дуже застаріла і не відповідає сучасним вимогам як до їі тактико-технічних характеристик, так і до вимог, що висуваються до захищеності від кінетичних засобів ураження.

Про низьку захищеність ББМ від кінетичних засобів ураження свідчить велика кількість броньованої техніки, яка втратила свою працездатність, або була безповоротно знищена стрілецькою зброєю противника найбільше під час активної фази антитерористичної операції (на сьогодні операції Об'єднаних сил) 2014 року. Дані випадки, на жаль, продовжують мати місце і на даний час.

Так, як ББМ (як застарілі, так і сучасні) складають більшу частину номенклатури озброєння і військової техніки військових частин Сухопутних військ та виконують великий перелік завдань в зоні бойових дій, пов'язаних зі збереженням житя особового складу, вони повинні мати достатній рівень протикульного захисту, вогневу потужність і протимінний захист.

На сьогодні, рівень броньового захисту ББМ у зв'язку з постійним підвищенням уражаючої здатності боєприпасів кінетичної дії вже не може забезпечити повною мірою вимоги щодо їх захищеності. Одним із шляхів вирішення даної проблеми є використання нового (сучасного) додаткового бронювання, яке 6 мінімально впливало на технічні характеристики ББМ та було економічно та практично обґрунтоване, а також ефективність його була б підтверджена за допомогою експериментальних випробувань [Горбачова, 2021].

\section{2. Теоретичні основи дослідження}

Дослідженню питань впливу засобів ураження на броньову перешкоду та підвищення рівня захищеності ББМ присвячена ціла низка робіт, як вітчизняних так і закордонних вчених, зокрема в роботі [Дачковський та інші, 2016] проведено аналіз ББМ, які запропоновані вітчизняним оборонно-промисловим комплексом України та визначені основні тенденції щодо їх розвитку. У публікації [Dachkovskyi, 2020] запропоновано методику визначення характеристик живучості зразка озброєння та військової техніки, що дає змогу визначати показники довговічності та відтворюваності зразків, визначаючи тим самим живучість окремого зразка озброєння та військової техніки (ОВТ) чи групи машин одноцільового призначення. Аналіз застосування захисних пристроїв під час ведення бойових дій, які виготовляються у військах, силами екіпажів зразків ОВТ проведено у роботі [Брель, 2018]. На основі даного аналізу запропоновано варіант класифікації таких пристроїв та сконцентрована увага на необхідність вивчення досвіду їх застосування. В літературному джерелі [Горбачова,2021] сформульовано вимоги до захищеності ББМ від кінетичної дії та на основі теоретико-множинного підходу представлено модель стійкості броньової перешкоди Глибоке опрацювання цієї проблеми відображене у публікації [Дачковський та інші, 2020] у якій для оцінювання відносних властивостей захисного екрану до уражаючої енергії засобів ураження проведено експериментальне дослідження, яке дозволило перевірити висунуту гіпотезу щодо застосування декількох слоїв матеріалів в захисних екранах для захисту ББМ від засобів ураження, які під дією кінетичної енергії руйнують броньову перешкоду. На основі отриманих даних під час експериментального дослідження побудовано математичну модель, яка описує імпульс пробиття захисного екрану. У роботі [Куртсеітов та інші, 2018] досліджено вплив засобів ураження на базові колісні платформи. Для перевірки базових колісних платформ на стійкість до засобів ураження запропонована методика експериментального дослідження. На основі експериментальних даних, отриманих під час лабораторного дослідження, побудовано математичну модель впливу засобів ураження на базові колісні платформи. Окремі аспекти 
даної проблематики викладені у роботі [Горбачова, 2019], яка присвячена аналізу тенденцій розвитку озброєння та військової техніки (ОВТ) Сухопутних військ, а саме шляхам підвищення їх захищеності від засобів ураження. Розглянуто напрями розвитку та основні конструктивні особливості ОВТ щодо забезпечення захисту від засобів ураження. У публікації [Загорянський, 2015] порівняні розрахункові критерії броньової стійкості різних протикульних захисних матеріалів (броньової сталі, броньової кераміки) з отриманим зварюванням вибухом біметалом сталь-алюміній як матеріалом для двошарової броні. Оптимальним визнаний розрахунковий критерій Стігліца. Підхід для оцінювання результатів впливу уламків елементів зовнішнього бронювання на внутрішнє обладнання ББМ за допомогою математичного моделювання процесів розльоту дії уламків на внутрішні агрегати машини визначено в роботі [Horbachova та інші, 2021] та наведено ймовірності ураження (пробиття) агрегату уламками, а також середньої кількості уламків, які можуть уразити відповідний агрегат. У літературному джерелі [Майстренко та інші, 2017] присвяченій числовому моделюванню процесу пробиття захисних керамічних елементів 3 різною конструкцією підтверджено ефективність розроблених захисних керамічних елементів для захисту ББМ. Але в даній роботі не визначено як засіб ураження втрачає енергетичні характеристики при пробитті броньової перешкоди. В роботі [Zhang Yiben та інші, 2019] запропонована модель кінцевих елементів, яка ґрунтується на даних, отриманих в результаті динамічних і статичних випробувань складових матеріалів, для прогнозування реакції і поведінки відмов гібридних пластин при малих швидкостях ударного навантаження. Під час даного дослідження враховували вплив швидкості ударника, кут його падіння, але не враховувалась відстань між додатковою перешкодою та основною бронею та товщина додаткової перешкоди. В публікації [Костюк та інші, 2014], присвяченій підвищенню рівня захищеності автомобілів багатоцільового призначення запропоновано множину варіантів технічних рішень щодо підвищення рівня балістичної захищеності. Приведено результати спостереження щодо уразливих ділянок автомобілів від стрілецької зброї, але не визначено, як саме підвищити рівень захищеності від засобів ураження. У джерелі [Голуб, 2013] запропонована методика обгрунтування рівня захищеності бойових колісних машин, що базується на визначенні кількості влучень у зразок під час його обстрілу 3 декількох засобів ураження. Вказана методика визначає середню кількість влучень у елементи зразка для обґрунтування технічних рішень щодо підвищення рівня його захисту. У публікації [Антипко та інші, 2016] розглянуто постановку завдання експериментального дослідження складового боєприпаса і програми випробувань для стрілецької зброї. А в роботах [Захисний екран корпусу броньованого автомобіля від кумулятивних реактивних гранат та куль, 2014; захисний екран бойових броньованих машин, 2019; броньована перешкода, 2020] пропонується створення додаткової захисної перешкоди корпусу ББМ від кумулятивних реактивних гранат та куль, що надасть можливість забезпечити ефективний захист ББМ від ураження енергією вибуху шляхом підвищення жорсткості броньованої перешкоди, збільшення площі поглинання енергії вибуху та дозволить зменшити прискорення, які виникають на лицьовому шарі броньованої перешкоди і передаються через тильний шар на екіпаж ББМ.

Але в цих працях не визначено, як засіб ураження буде втрачати кінетичну енергію в залежності від кута зустрічі засобу ураження із броньовою перешкодою, $\gamma$, град, відстані від броньової перешкоди до броні, $l$, см та товщини броньової перешкоди, $h$, мм, а також вплив засобів ураження на броньову перешкоду ББМ в залежності від факторів, що впливають на процес пробиття додаткового захисту. 


\section{3. Результати}

В роботах [Златина та інші, 1974; Лавренчик, 1986] було запропоновано ряд вимог щодо проведення лабораторного дослідження впливу засобів ураження на додаткову броньову перешкоду. В цьому випадку серед лабораторного устаткування необхідно використати балістичний маятник. Це дозволить дослідити стійкість додаткової броньової перешкоди до кінетичної енергії засобів ураження.

Для оцінювання стійкості додаткового бронювання обрана методика дослідження параметрів пробою з реєстрацією ударного імпульсу, що дозволяє проводити експрес-оцінку опору матеріалів деформуванню й руйнуванню при наскрізному пробитті [Джонсон та інші, 1981; Астанін та інші, 2009]. При цьому можливо отримати кількісну оцінку стійкості матеріалу конструкції броньової перешкоди до пробою з урахуванням умов взаємодії, фізикомеханічних властивостей і геометричних параметрів ударника і перешкоди. Суть методики полягає в тому, що зразки додаткового бронювання пробиваються ударниками навиліт, в результаті чого маятнику передається ударний імпульс, який викликає відхилення останнього від положення рівноваги на величину $L$, по яким можливо розрахувати енергетичні втрати, які обумовлені деформуванням і руйнуванням перешкоди (рис. 1).

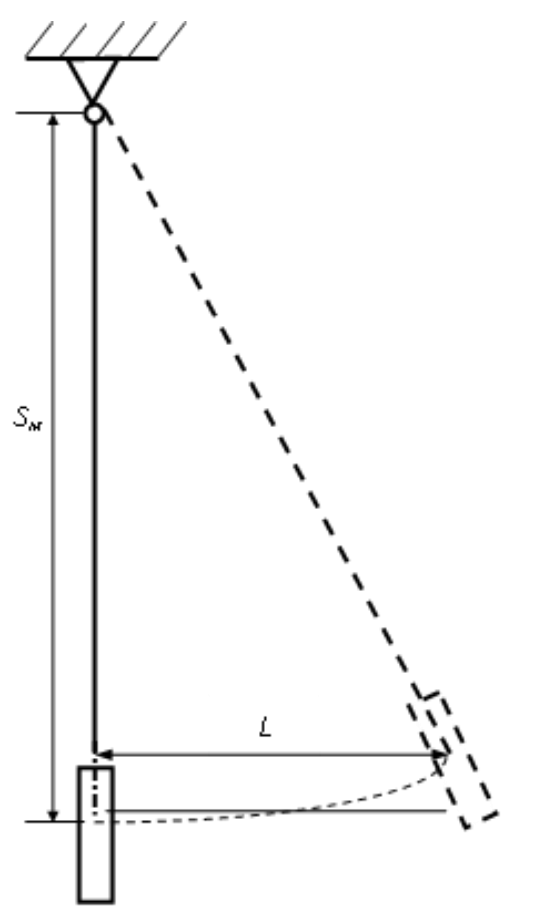

Рисунок 1 - Схема балістичного маятника

Джерело: розроблено автором

Методика проведення лабораторних досліджень (випробувань) складається з ряду складових. До них відносять підготовку до проведення лабораторних досліджень (випробувань), оцінку стійкості броньової перешкоди до кінетичної енергії засобів ураження 3 визначеними параметрами. В свою чергу, підготовка лабораторного дослідження включає в себе обгрунтування вимог і підготовку лабораторного обладнання, а саме, балістичного маятника, балістичного ствола, вимірювача швидкості ИБХ-733.0 та іншого необхідного лабораторного устаткування, наведеного в табл. 1. Наступним етапом, за підготовкою, $\epsilon$ проведення лабораторних досліджень впливу кінетичної енергії засобів ураження на додаткову перешкоду та на корпус ББМ. Після цього проводиться систематизація отриманих експериментальних результатів. За їх допомогою визначаються: імпульс пробиття $I_{\Pi}$ та енергетичні витрати $E$, обумовлені деформуванням і руйнуванням додаткової перешкоди, 
після чого визначається залишкова енергія засобу ураження, яка впливатиме на корпус ББМ і порівнюється зі стійкістю основного бронювання для визначення ступеня пошкодження. На останньому етапі визначається оцінка ефективності захисту, що пропонується.

Дослідження протикульної стійкості додаткового захисту (зразків додаткового бронювання) проводилися В балістичній трасі науково-випробувального відділу Національного університету оборони України імені Івана Черняховського згідно вимог державних стандартів [ДСтУ 3975-2000] на експериментальній установці (рис. 2).

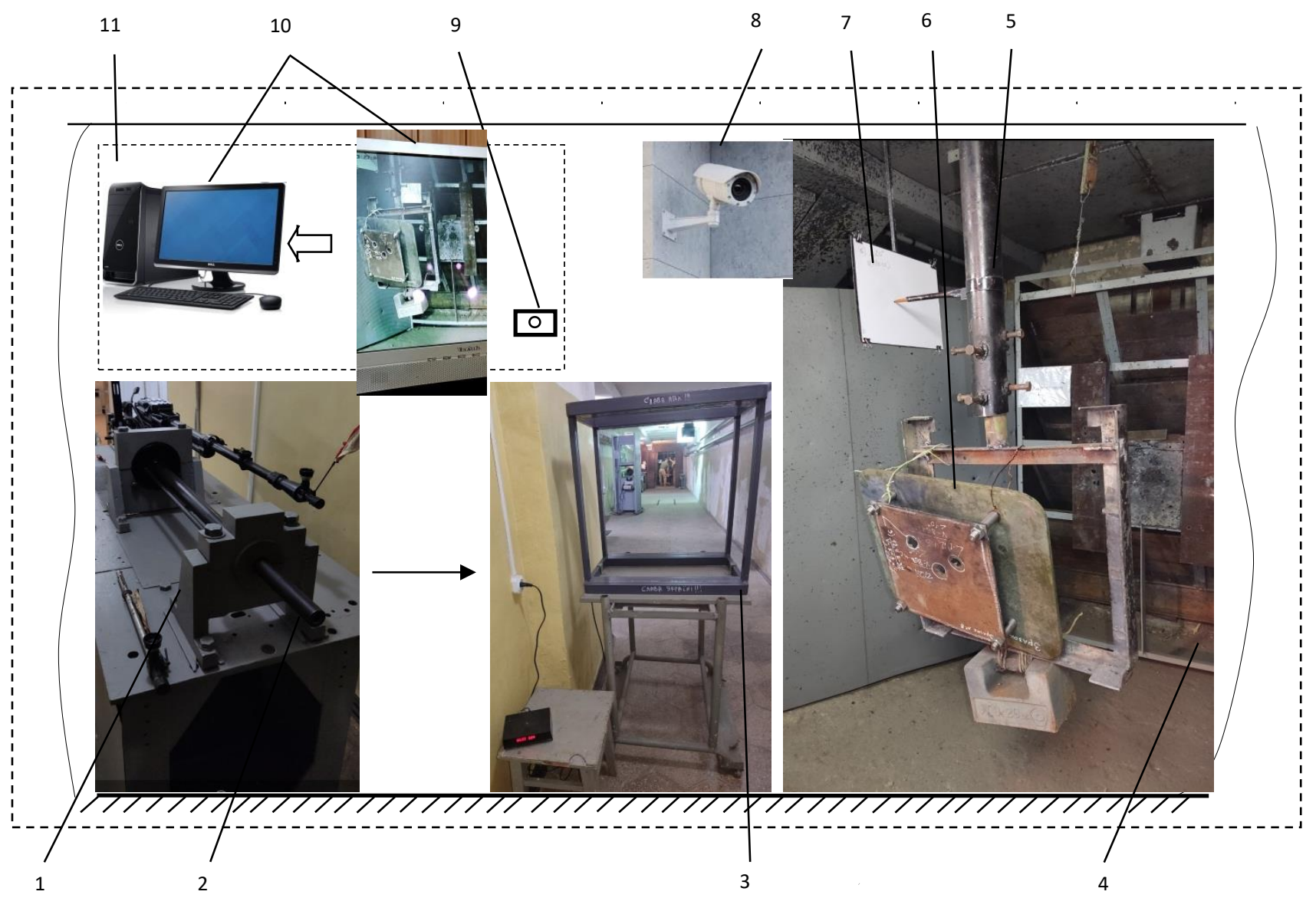

Рисунок 2 - Схема розміщення лабораторного обладнання:

1 - стенд кріплення балістичного ствола; 2 - ствол; 3 - пристрій визначення швидкості кулі; 4 - кулеутримувач; 5 - балістичний маятник; 6 - зразок додаткового бронювання, що досліджується; 7 - відображення реєстрації відхилення маятника; 8 - відеокамера; 9 - дистанційний електроспуск, 10 -.монітор; 11 - пультова кімната

Джерело: розроблено автором.

Дослідження проводилось за наступних нормальних кліматичних умов [ДСТУ 3975-2000]:

- температура навколишнього середовища $-20 \pm 5^{\circ} \mathrm{C}$;

- відносна вологість - не більше $80 \%$;

- атмосферний тиск - 87 - 107 кПа.

Об'єктом випробування обрано додатковий захист броні (рис. 3), виконаний із зразків сталі 30 ХГСА товщиною 5 мм, 10 мм та 15 мм, що кріпились до броньового листа за допомогою металевих шпильок на відстані 50 мм, 100 мм, 150 мм та під кутом 10 $20^{\circ}, 30^{\circ}$ відповідно.

Перед початком досліджень проводилось тарування балістичного маятника. Для цього використовувався зразок, який не пробивається ударником при пострілі. В такому випадку, вся енергія кулі витрачається на відхилення маятника від рівновісного стану. При таруванні використовувалися ударники і зразок сталі 30 ХГСА. У якості ударника використовувалися 12,7×108 мм патрони з бронебійно-запалювальною кулею Б-32. 


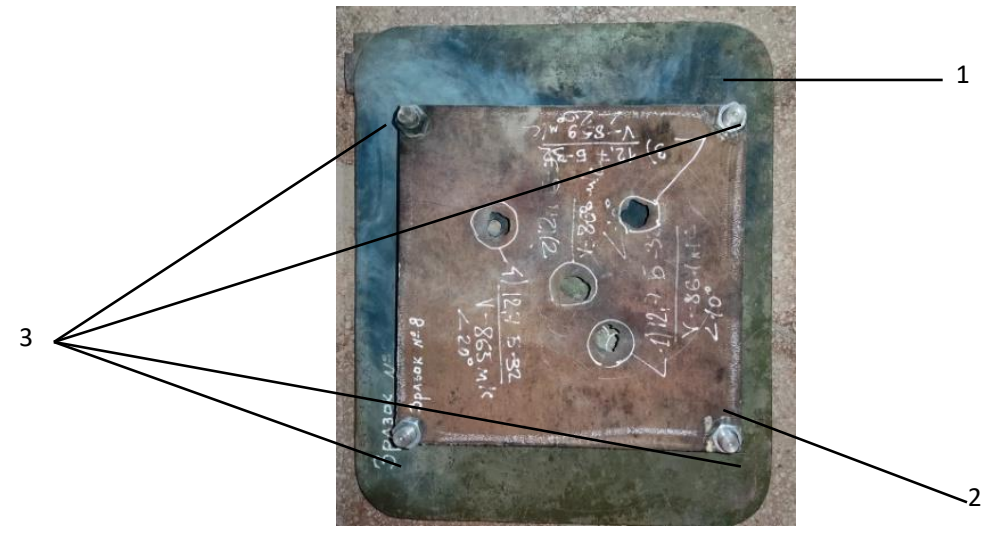

Рисунок 3 - Конструкція додаткового захисту броні:

1 - броньова плита, 2 - сталь 30 ХГСА , 3 - шпильки, за допомогою яких здійснено кріплення сталі 30 ХГСА до броньового листа Джерело: розроблено автором.

Всі постріли здійснювались по нормалі до площини зразка. Товщину зразка вибрано з урахуванням забезпечення його не пробиття. При визначенні тарувального коефіцієнта для кожного пострілу використовувалось наступне співвідношення:

$$
k_{\text {пi }}=\left(\mathrm{mV}_{2,5}\right)\left(S_{p}\right)^{-1}
$$

де $k_{\mathrm{ni}}$ - тарувальний коефіцієнт балістичного маятника для кожного пострілу;

$m$ - маса кулі, кг;

$V_{2,5}$ - швидкість кулі на відстані 10 м від зрізу ствола, м/с;

$S_{p}$ - величина відхилення маятника від свого рівновісного стану після влучення кулі у зразок, м.

Для визначення тарувального коефіцієнта було проведено три серії експериментів враховуючи різні швидкості кулі. У відповідності до отриманих даних кожного пострілу було визначено середнє значення тарувального коефіцієнта:

$$
k_{n}=\left(\sum_{i=1}^{N} k_{n i}\right)(N)^{-1}
$$

Під час проведення лабораторного дослідження протикульної стійкості додаткового бронювання використовувався балістичний маятник вагою 20,16 кг з довжиною маятника від точки влучення кулі у зразок до осі шарнірного з'єднання $S_{M}$ 1,2 м (рис. 1). Для збільшення ваги маятника було використано гирю 20 кг, що кріпилася в його основі. Маятник підвішувався до стелі в кулеутримувачі балістичної траси. До маятника кріпився дослідний зразок змінюючи умови проведення експерименту під час кожного пострілу: кут нахилу броньової перешкоди відносно маятника, що вимірювався за допомогою кутоміра з ноніусом та відстань додаткового захисту до броньового листа, що регулювалася за допомогою металевих шпильок різної довжини.

Далі проводилось заряджання балістичного ствола. Під час заряджання та проведення пострілу, всі присутні перебували у захищеній від пробиття пультовій кімнаті та мали можливість спостерігати за експериментом, відеозображення якого через відеокамеру передавалося на монітор комп'ютера та автоматично записувалося в електронному вигляді у пам'ять відеореєстратора.

Обстріл проводився з балістичного ствола поодинокими пострілами, закріпленого в спеціальному пристрої кріплення виробу, обладнаному системою дистанційного електроспуску, що знаходиться в пультовій та системою лазерного прицілювання. Ударник 
розганявся пороховими газами по каналу балістичного ствола, який на швидкостях $853-874 \mathrm{~m} / \mathrm{c}$ взаємодіяв із броньовою перешкодою. Після пробою він попадав у мішенну камеру (кулеутримувач), який забезпечує безпечне утримання куль і їх фрагментів, а також осколків зразків при проведенні балістичних випробувань. Швидкість кулі при пострілі вимірювалася оптоелектронним вимірювальним комплексом ИБХ-733.0, що розташовувався на відстані 10 м від зрізу каналу ствола. Відстань від зрізу балістичного ствола до точки ураження зразка, який жорстко закріплений на балістичному маятнику, становила 33 м.

Під час впливу кулі на зразок, що закріплений на маятнику, забезпечувалася реєстрація відхилення балістичного маятника, викликана ударним імпульсом, який переданий кулею на перешкоду при їхній взаємодії.

Взаємне розміщення балістичного ствола, вимірювача швидкості і балістичного маятника було сталим, змінювався лише кут нахилу досліджуваного зразка, що кріпився до маятника та відстань від додаткової перешкоди до броньового листа відповідно до плану експериментального дослідження [Барабащук та інші, 1984].

Перелік випробувального обладнання та засобів вимірювальної техніки, що були використані при проведенні дослідження, наведений в табл. 1.

Таблиця 1 - Перелік випробувального обладнання та засобів вимірювальної техніки

\begin{tabular}{|c|c|c|c|c|c|c|c|}
\hline \multirow{2}{*}{$\begin{array}{l}\text { № } \\
3 / \pi\end{array}$} & \multirow[b]{2}{*}{ Найменування } & \multirow{2}{*}{$\begin{array}{l}\text { Завод. } \\
\text { № }\end{array}$} & \multirow{2}{*}{$\begin{array}{c}\text { Характеристики, } \\
\text { що } \\
\text { визначаються }\end{array}$} & \multirow{2}{*}{$\begin{array}{l}\text { Діапазон } \\
\text { вимірів }\end{array}$} & \multirow{2}{*}{$\begin{array}{l}\text { Точність } \\
\text { (похибка) }\end{array}$} & \multicolumn{2}{|c|}{ Дата калібрування } \\
\hline & & & & & & останньої & наступної \\
\hline 1 & $\begin{array}{l}\text { Вимірювальний комплекс } \\
\text { оптоелектронний } \\
\text { ИБХ-733.0 }\end{array}$ & ХК 089 & $\begin{array}{l}\text { Швидкість } \\
\text { польоту кулі }\end{array}$ & $\begin{array}{c}1-2000 \\
\mathrm{M} / \mathrm{C}\end{array}$ & $0,1 \mathrm{~m} / \mathrm{c}$ & $03.21 \mathrm{p}$ & $03.23 \mathrm{p}$. \\
\hline 2 & $\begin{array}{l}\text { Ваги електронні } \\
\text { ВН-150-1-D-a }\end{array}$ & 54720 & Визначення ваги & 1 $0,4 \ldots 150 \mathrm{kr}$ & $\pm 0,04$ г & $03.21 \mathrm{p}$. & $03.23 \mathrm{p}$. \\
\hline 3 & $\begin{array}{l}\text { Рулетка вимірювальна } \\
\text { Р5Узк }\end{array}$ & 17 & $\begin{array}{l}\text { Визначення } \\
\text { довжини }\end{array}$ & $0 \ldots 5 \mathrm{M}$. & $0,09 \mathrm{MM}$ & $09.20 \mathrm{p}$ & $09.23 \mathrm{p}$. \\
\hline 4 & $\begin{array}{l}\text { Штангенциркуль } \\
\text { цифровий Шцц-1 }\end{array}$ & $\begin{array}{c}\text { GX } \\
12031275 \\
\end{array}$ & $\begin{array}{r}\text { Визна } \\
\text { дови }\end{array}$ & $0 \ldots 200 \mathrm{Mm}$, & $\pm 0,05 \mathrm{Mm}$ & $03.21 \mathrm{p}$. & $03.23 \mathrm{p}$. \\
\hline 5 & $\begin{array}{l}\text { Штангенглибиномір ШГ. } \\
200\end{array}$ & 533.501 & $\begin{array}{l}\text { Визначення } \\
\text { глибини }\end{array}$ & $0 \ldots 200 \mathrm{~mm}$, & $\pm 0.05 \mathrm{Mm}$ & $03.21 \mathrm{p}$ & $03.23 \mathrm{p}$. \\
\hline 6 & Кутомір з ноніусом & 16 & Визначення кута & $1 \ldots 180^{\circ} \mathrm{C}$ & $0,74^{\circ}$ & $03.21 \mathrm{p}$. & $03.23 \mathrm{p}$. \\
\hline 7 & Лінійка металева 500 мм & 18 & Лінійні розміри & $0 . .500 \mathrm{~mm}$ & 0,060 & $03.21 \mathrm{p}$. & $03.23 \mathrm{p}$. \\
\hline 8 & $\begin{array}{l}\text { Барометр-анероїд } \\
\text { контрольний М-98 }\end{array}$ & 509 & $\begin{array}{l}\text { Атмосферний } \\
\text { тиск }\end{array}$ & \begin{tabular}{|l|}
300.820 \\
ммрт.с.
\end{tabular} & \pm 1 мм рт.ст & $11.20 \mathrm{p}$ & $11.23 \mathrm{p}$. \\
\hline 9 & $\begin{array}{l}\text { Гігрометр } \\
\text { психометричний ВИТ-1 }\end{array}$ & A001 & $\begin{array}{c}\text { Визначення } \\
\text { температури та } \\
\text { вологості } \\
\end{array}$ & $\begin{array}{l}0 \ldots 90 \% . \\
0 \ldots 25^{\circ} \mathrm{C}\end{array}$ & $\pm 0,24 \mathrm{MM}$ & $03.21 \mathrm{p}$. & $03.23 p$. \\
\hline 10 & $\begin{array}{l}\text { Гігрометр } \\
\text { психометричний ВИТ-2 }\end{array}$ & 5070 & $\begin{array}{c}\text { Визначення } \\
\text { температури та } \\
\text { вологості } \\
\end{array}$ & $\begin{array}{l}0 . . .90 \% . \\
15 \ldots 40^{\circ} \mathrm{C}\end{array}$ & $\pm 0,24 \mathrm{MM}$ & $03.21 \mathrm{p}$ & $03.23 \mathrm{p}$. \\
\hline
\end{tabular}

Джерело: розроблено автором.

\section{4. Результати та обговорення}

Отже, у відповідності до вибраного плану дослідження та лабораторного устаткування отримано ряд експериментальних даних, які наведено в табл. 2. 
Таблиця 2 - Дані, отримані під час проведення експерименту

\begin{tabular}{|c|c|c|c|c|}
\hline $\begin{array}{c}\text { № } \\
\text { досліду }\end{array}$ & $\begin{array}{c}\text { Кут зустрічі засобу } \\
\text { ураження із броньовою } \\
\text { перешкодою, } \gamma, \text { град.і }\end{array}$ & $\begin{array}{c}\text { Відстань від } \\
\text { броньової перешкоди } \\
\text { до броні, } l, \text { см }\end{array}$ & $\begin{array}{c}\text { Товщина } \\
\text { броньової } \\
\text { перешкоди, } h, \text { мм }\end{array}$ & $\begin{array}{c}\text { Швидкість } \\
\text { засобу } \\
\text { ураження, } v, \\
\text { м/с. }\end{array}$ \\
\hline 0 & 20 & 15 & 10 & 872 \\
\hline 1 & 30 & 15 & 10 & 858 \\
\hline 2 & 10 & 15 & 10 & 862 \\
\hline 3 & 30 & 5 & 10 & 869 \\
\hline 4 & 10 & 5 & 10 & 861 \\
\hline 5 & 20 & 10 & 10 & 861 \\
\hline 6 & 20 & 15 & 15 & 873 \\
\hline 7 & 20 & 15 & 5 & 867 \\
\hline 8 & 20 & 5 & 15 & 859 \\
\hline 9 & 20 & 5 & 5 & 865 \\
\hline 10 & 20 & 10 & 10 & 873 \\
\hline 11 & 30 & 10 & 15 & 861 \\
\hline 12 & 30 & 10 & 5 & 863 \\
\hline 13 & 10 & 10 & 15 & 853 \\
\hline 14 & 10 & 10 & 5 & 874 \\
\hline 15 & 20 & 10 & 10 & 862 \\
\hline
\end{tabular}

\section{5. Висновки}

В подальшому, використовуючи отримані експериментальні дані буде побудовано математичну модель впливу засобів ураження, а саме кулі 7,62 мм, 12,7 мм, 14,5 мм на додаткову броньову перешкоду з метою обгрунтування достовірності і перевірки адекватності моделі впливу засобів ураження на додаткову броньову перешкоду, що дасть можливість визначати мінімально-необхідний рівень додаткового бронювання.

\section{6. Фінансування}

Це дослідження не отримало конкретної фінансової підтримки.

\section{7. Конкуруючі інтереси}

Автори заявляють, що у них немає конкуруючих інтересів.

\section{Список використаних джерел}

1. Горбачова Я. С. Дослідження захищеності сучасних бойових броньованих машин від кінетичних засобів ураження. Проблемні питання щодо ремонту новітніх зразків озброєння та військової техніки: матеріали наук.-практ. сем. (м. Київ, 18 листоп. 2021 р.). Київ, 2021. С. 17-18.

2. Дачковський В.О., Овчаренко І.В. Аналіз розвитку бойових броньованих машин. Сучасні інформачійні

\section{References}

1. Horbachova, Y. (2021). Doslidzhennya zakhystu suchasnoyi boyovoyi bronetekhniky vid kinetychnykh zasobiv urazhennya [Research of protection of modern combat armored vehicles from kinetic means of destruction]. Problematic issues related to the repair of the latest models of weapons and military equipment: materials of the scientific-practical seminar, Kyiv, 17-18. (in Ukrainian).

2. Dachkovskyi, V., \& Ovcharenko, I. (2016). Analiz rozvytku boyovykh bron'ovanykh mashyn [Analysis of the 
технології у сорері безпеки та оборони. 2016. № 2(26) С. 127 - 132. URL:

http://nbuv.gov.ua/UJRN/sitsbo_2016 -2_24.

3. Dachkovskyi V.O. Method of determination of survival characteristics of weapons and military equipment. Social development \& Security. 2020. №10(1), C. 18 - 24. DOI : 10.33445/sds.2020.10.1.3

4. Брель М. П. Анализ применения нестандартних защитных устройств для боевых бронированных машин. Сборник научных статей военной академии Республики Беларусь. 2018. № 34. С. 127-134.

5. Горбачова Я. С. Формулювання вимог до захищеності бойових броньованих машин від ураження боєприпасами кінетичної дії. Journal of Scientific Papers Social development \& Security. Vol. 11. Issue 2. April, 2021. P. 115-124. DOI : 10.33445/sds.2021.11.2.12.

6. Дачковський В. О., Даценко І. П., Коцюруба В. І., Яльницький О. Д., Голда О. Л., Неділько О. М., Сиротенко А. М. Експериментальне дослідження впливу засобів ураження на захисні екрани бойових броньованих машин. Опір матеріалів і теорія споруд: наук.-тех. збірн. Київ: КНУБА, 2020. Вип. 104. С. 117-135.

7. Куртсеітов Т. Л., Дачковський В. О., Кізяк Я. О., Угринович О. І. Експериментальне дослідження стійкості базових колісних платформ до впливу вибухонебезпечних предметів. Natural, Mathematical and Technical science NaMaTech. 2018, Held in Budapest on 16th of December 2018. DOI: 10.31174/SEND-NT2018-186VI2215.

8. Горбачова Я., Лисий М., Мисик А., Дачковський В. Напрямки розвитку озброєння та військової техніки щодо підвищення рівня захищеності: зб. наук. праць Національної академії Державної прикордонної служби України Серія: військові та технічні науки. 2019. № 3 (87). C. 411-428. DOI : 10.32453/3.V81i3.483.

9. Загорянський В.Г. Обоснование применимости биметалла сталь- development of combat armored vehicles]. Modern information technologies in the field of security and defense, 2(26), 127 - 132. (in Ukrainian). http://nbuv.gov.ua/UJRN/sitsbo_2016_2_24.

3. Dachkovskyi, V. (2020). Method of determination of survival characteristics of weapons and military equipment. Social development \& Security, 10(1), 18 - 24. DOI: $10.33445 /$ sds.2020.10.1.3.

4. Brel, M. (2018). Analiz primeneniya nestandartnikh zashchitnykh ustroystv dlya boyevykh bronirovannykh mashin [Analysis of the use of nonstandard protective devices for armored combat vehicles]. Collection of scientific articles of the military academy of the Republic of Belarus, 34, 127-134. (in Belarus).

5. Horbachova, Y. (2021). Formulyuvannya vymoh do zakhyshchenosti boyovykh bron'ovanykh mashyn vid urazhennya boyeprypasamy kinetychnoyi diyi [Formulation of requirements for the protection of armored combat vehicles from kinetic munitions damage]. Journal of Scientific Papers Social development \& Security, Vol. 11, Issue 2. April, 115124. DO I: 10.33445/sds.2021.11.2.12.

6. Dachkovskyi, V., Datsenko, I., Kotsiuruba, V., Yalnytskyi, O., Holda, O., Nedilko, O. \& Syrotenko, A. (2020). Eksperymental'ne doslidzhennya vplyvu zasobiv urazhennya na zakhysni ekrany boyovykh bron'ovanykh mashyn [Experimental study of the effect of means of destruction on the protective screens of armored combat vehicles]. Resistance of materials and theory of structures: scientific and technical, team Issue 104, 117-135. (in Ukrainian).

7. Kurtseitov, T., Dachkovskyi, V., Kiziak, Y. \& Uhrynovych, O. (2018). Experimental study of the resistance of basic wheel platforms to the effects of explosive objects. Natural, Mathematical and Technical science NaMaTech. Held in Budapest on 16th of December 2018. DO I: 10.31174/SEND-NT2018186VI22-15.

8. Horbachova, Y., Lysyi, M. \& Dachkovskyi, V. (2019). Napryamky rozvytku ozbroyennya ta viys'kovoyi tekhniky shchodo pidvyshchennya rivnya zakhyshchenosti [Areas of development of armaments and military equipment to increase the level of security]. Collection of scientific works of the National Academy of the State Border Guard Service of Ukraine. Series: Military and Technical Sciences, 81 (3), 391-408. (in Ukrainian). DOI: 10.32453/3.V81i3.483.

9. Zahorianskyi, V. (2015). Obosnovaniye primenimosti bimetalla stal'-alyuminiy po raschetnym kriteriyam protivopul'noy bronestoykosti [Justification of the 
алюминий по расчетным критериям противопульной бронестойкости. Вісник нТУу "КПІ".Серія: машинобудування. Кременчуг. № 3 (75). 2015. C. 37-41.

10. Horbachova Y, Dachkovskyi V. Modeling of the behind armor action of fragments of armor obstacle on elements of combat armored vehicles. Political Science and Security Studies Journal. 2021. № 2(1). P. 26-32.

DO I: 10.5281/zenodo.4646156.

11. Майстренко А. Л., Кущ В. І., Кулич В. Г., Нешпор О. В., Бісик С. П. Підвищення захисту бойових броньованих машин від ураження 12,7-мм кулями Б-32. Озброєння та військова техніка. Київ, 2017. № 1(13). С. 18-23. DOI : 10.34169/2414-0651.2017.1(13).18-23.

12. Zhang Yiben, Sun Lingyu, Li Lijun, Wang Taikun, Shen Le Experimental and numerical investigations on lowvelocity impact response of high strength steel/composite hybrid plate. International. Journal of Impact Engineering. 2019. Vol. 123. P. 1-13. DOI : 10.1016/j.ijimpeng.2018.08.015

13. Костюк В. В., Русіло П. О., Калінін О. М., Будяну Р. Г., Варванець Ю. В. Оцінка підвищення рівня захищеності автомобілів багатоцільового призначення. Вісник НТУ«ХПІ», 2014, №14(1057). С. 1-9.

14. Голуб В. А. Методика обгрунтування рівня захищеності бойових колісних машин. Системи озброєння $i$ військова техніка. Київ, 2013. № 3 (35). С. 9-12.

15. Антипко О. Б., Бирюков И. Ю., Сыщук С. И., Щепцов А. В. Постановка задачи экспериментального исследования составного боеприпаса и программа испытаний для стрелкового оружия. Система озброєння і військова техніка. 2016. № 1 (45). С. 10-13.

16. Захисний екран корпусу броньованого автомобіля від кумулятивних реактивних гранат та куль: пат. 98190 Україна: МПК (2009) F41H7/02. № u201410031; заяв. 12.09.2014; опубл. 27.04.2015; Бюл. № 8.

17. Захисний екран бойових броньованих машин: пат. 132190 Україна: МПК applicability of the steel-aluminum bimetal according to the design criteria for bulletproof armor resistance]. Bulletin of NTUU "KPI". Series: mechanical engineering. Kremenchug, 3 (75), 3741. (in Ukrainian).

10. Horbachova, Y. \& Dachkovskyi, V. (2021). Modeling of the behind armor action of fragments of armor obstacle on elements of combat armored vehicles. Political Science and Security Studies Journal, 2(1). 26-32. DOI : 10.5281/zenodo.4646156.

11. Maistrenko, A., Kushch, V., Kulych, V., Neshpor, O. \& Bisyk, S. (2017). Pidvyshchennya zakhystu boyovykh bron'ovanykh mashyn vid urazhennya 12,7-mm kulyamy B-32 [Improving the protection of armored combat vehicles from $12.7-\mathrm{mm}$ bullets B-32]. Arms and Military Equipment, 9 (1), 18-23. (in Ukrainian). DOI : 10.34169/24140651.2017.1(13).18-23

12. Zhang, Y., Sun, L., Li, L., Wang, T., \& Shen, L. (2019). Experimental and numerical investigations on lowvelocity impact response of high strength steel/composite hybrid plate. International Journal of Impact Engineering, 123, 1-13. DOI : 10.1016/j.ijimpeng.2018.08.015

13. Kostiuk, V., Rusilo, P., Kalinin, O., Budianu, R. \& Varvanets, Y. (2014). Otsinka pidvyshchennya rivnya zakhyshchenosti avtomobiliv bahatotsil'ovoho pryznachennya [Assessment of increasing the level of protection of multi-purpose vehicles]. Bulletin of NTU "KhPI", 14 (1057), 1-9. (in Ukrainian).

14. Holub, V. (2013). Metodyka obgruntuvannya rivnya zakhyshchenosti boyovykh kolisnykh mashyn [Methods of substantiation of the level of protection of combat wheeled vehicles]. Weapons systems and military equipment, 3 (35), 9-12. (in Ukrainian).

15. Antypko, O., Byriukov, I., Syshchuk, S. \& Shcheptsov, A. (2016). Postanovka zadachi eksperimental'nogo issledovaniya sostavnogo boyepripasa i programma ispytaniy dlya strelkovogo oruzhiya [Statement of the problem of an experimental study of a composite ammunition and a test program for small arms]. Weapons system and military equipment. 1 (45). 10-13. (in Ukrainian).

16. Dachkovskyi, V., Datsenko, I., Melnyk, B., Trach, O. \& Boiko, O. (2014). Zakhysnyy ekran korpusu bron'ovanoho avtomobilya vid kumulyatyvnykh reaktyvnykh hranat ta kul' [Protective shield of the body of the armored vehicle from cumulative jet grenades and bullets]: patent 98190 Ukraine: IPC (2009) F41H7 / 02 . № u201410031; filed 
(2009) F41H5/04. № u201809885; заяв. 03.10.2018; опубл. 11.02.2019; Бюл. № 3/2019.

18. Броньована перешкода: пат. 143200 Україна: МПК (2009) F41H7/02. № u202002105; заяв. 30.03.2020; опубл. 10.07.2020; Бюл. № 13

19. Златина Н. А., Мишина Г.И. Балистические установки и их применение в экспериментальных исследованиях / под ред. Н.А. Златина и Г.И. Мишина. Москва: Наука, 1974. С. 12-187.

20. Лавренчик В. Н. Постановка физического эксперимента и статистическая обработка его результатов: учебн. пособ. для вузов. Москва: Энергоатомиздат, 1986. 272 с.

21. Джонсон Н., Лион Ф. Статистика и планирование эксперимента в технике и науке: Методы планирования эксперимента (пер. с англ. под ред. Лецкого Э. К., Марковой Е. В.). Москва: Мир, 1981. $520 \mathrm{c}$.

22. Астанін В. В., Олефір Г. О. Застосування балістичного маятника для досліджень ударної міцності матеріалів. Наукоємні технології. Київ, 2009. № 2. С. 19-24

23. ДСТУ 3975-2000. Захист панцерових спеціалізованих автомобілів. Загальні технічні вимог. [Чинний від 2001-0101]. Київ: Держстандарт України, 2000. 8 с. (Інформація та документація).

24. Барабащук, В.И. Креденцер, Б. П., Мирошниченко В.И. Планирование эксперимента в технике. Киев: Техника, 1984. 200 с.
12.09.2014; published on April 27, 2015; Bull. № 8 . (in Ukrainian).

17. Dachkovskyi, V., Kurovska, T. \& Sampir, O. (2018). Zakhysnyy ekran boyovykh bron'ovanykh mashyn [Protective shield of combat armored vehicles]: patent 132190 Ukraine: IPC (2009) F41H5 / 04. № u201809885; application 03.10.2018; published on February 11, 2019; Bull. № 3/2019. (in Ukrainian).

18. Horbachova, Y., Dachkovskyi, V., Bisyk, S. \& Aristarkhov, O. (2020). Bron'ovana pereshkoda [Armored obstacle]: patent 143200 Ukraine: IPC (2009) F41H7 / 02. № u202002105; application 30.03.2020; published 10.07.2020; Bull. № 13. (in Ukrainian).

19. Zlatyna, N. \& Mishyna, H. (1974). Balisticheskiye ustanovki i ikh primeneniye v eksperimental'nykh issledovaniyakh [Ballistic Installations and Their Application in Experimental Research]. Moscow: Nauka, 12-187. (in Russian).

20. Lavrenchyk, V. (1986). Postanovka fizicheskogo eksperimenta i statisticheskaya obrabotka yego rezul'tatov [Setting up a physical experiment and statistical processing of its results]. Moscow: Energoatomizdat, 272. (in Russian).

21. Dzhonson, N. \& Lyon, F. (1981). Statistika i planirovaniye eksperimenta $v$ tekhnike i nauke: Metody planirovaniya eksperimenta [Statistics and Experiment Design in Engineering and Science: Experiment Planning Methods]. (translation from English). Moscow: Mir, 520. (in Russia).

22. Astanin, V. \& Olefir, H. (2009). Zastosuvannya balistychnoho mayatnyka dlya doslidzhen' udarnoyi mitsnosti materialiv [The use of a ballistic pendulum to study the impact strength of materials]. Scienceintensive technologies, 2 (2), 19-24. (in Ukrainian).

23. DSTU 3975-2000. (2000). Zakhyst pantserovykh spetsializovanykh avtomobiliv. Zahal'ni tekhnichni vymohy [Protection of armored specialized vehicles. General technical requirements]. Kyiv: State Standard of Ukraine, 8. (Information and documentation). (in Ukrainian).

24. Barabashchuk, V., Myroshnychenko, V. \& Kredentser, B. (1984). Planirovaniye eksperimenta $\vee$ tekhnike [Experiment planning in engineering]. Technique, 200. (in Russian). 